\title{
PENERAPAN MODEL PEMBELAJARAN ARIAS (ASSURANCE, RELEVANCE, INTEREST, ASSESSMENT, SATISFACTION) UNTUK MENINGKATKAN HASIL BELAJAR MENULIS KARANGAN NARASI PADA SISWA KELAS IV SDN 118 PINRANG
}

\author{
Hasnah \\ PGSD UPP Parepare Fakultas Ilmu Pendidikan UNM \\ hasnahunm@yahoo.co.id
}

\begin{abstract}
ABSTRAK
Permasalahan penelitian ini adalah apakah model pembelajaran arias (assurance, relevance, interest, assessment, satisfaction) dapat meningkatkan hasil belajar menulis karangan narasi pada siswa kelas IV SDN 118 Pinrang. Tujuan penelitian ini yaitu untuk mengetahui penerapan model pembelajaran arias (assurance, relevance, interest, assessment, satisfaction) dapat meningkatkan hasil belajar menulis karangan narasi pada siswa kelas IV SDN 118 Pinrang. Pendekatan yang digunakan dalam penelitian ini adalah pendekatan deskriptif kualitatif. Jenis Penelitian yang dilakukan adalah penelitian tindakan kelas yang berdaur ulang/siklus. Tindakan dalam penelitian ini dilakukan dua siklus yang mana setiap siklus melalui empat tahap yaitu perencanaan, pelaksanaan, observasi, dan refleksi. Data diperoleh melalui tes, observasi, dan dokumentasi. Teknik analisis yang digunakan dalam penelitian ini adalah analisis deskriptif kualitatif. Berdasarkan hasil penelitian diperoleh data pada siklus I berada pada kategori kurang, siklus II pada kategori cukup dan siklus III pada kategori sangat baik. Dengan demikian dapat disimpulkan bahwa model pembelajaran ARIAS (assurance, relevance, interest, assessment, satisfaction) dapat meningkatkan hasil belajar menulis karangan narasi pada siswa kelas IV SDN118 Pinrang.
\end{abstract}

Kata Kunci: model pembelajaran ARIAS, menulis karangan narasi.

\section{PENDAHULUAN}

Pendidikan adalah suatu usaha sadar yang mempunyai tujuan pasti dalam pembelajaran. Sebagai usaha sadar, hakikat pendidikan mengacu pada usaha untuk membudayakan manusia atau memanusiakan manusia.

Menurut Abidin (2012) menyatakan bahwa Pembelajaran menulis sampai saat ini menjadi bahan penelitian yang digemari. Kondisi ini sejalan dengan kenyataan bahwa pembelajaran menulis masih menyisakan sejumlah masalah serius. Salah satu masalah serius tersebut adalah rendahnya keterampilan siswa dalam menulis. Berbagai penelitian menunjukkan bahwa keterampilan menulis sejak tingkat sekolah dasar hingga perguruan tinggi masih memprihatinkan.
Rendahnya keterampilan siswa dalam menulis disebabkan oleh berbagai faktor. Salah satu faktor yang dominan adalah rendahnya peran guru dalam membina siswa agar terampil menulis. Pembelajaran menulis yang seharusnya membina para siswa untuk berlatih mengemukakan gagasan masih belum secara optimal dikembangkan. Hasil tulisan siswa juga terkadang hanya dinilai dari jumlah paragraf yang dihasilkan, kerapian tulisan, dan faktor lain yang tidak esensial. Penilaian yang demikian juga jelas bukanlah sebuah penilaian yang berfungsi untuk membangun keterampilan menulis siswa bahkan sebaliknya bisa menghancurkan kemampuan menulis siswa yang sesungguhnya.

Menulis merupakan salah satu keterampilan yang perlu dimiliki oleh siswa 
Sekolah Dasar. Dengan memiliki keterampilan menulis, siswa dapat mengomunikasikan ide, penghayatan, dan pengalamannya ke berbagai pihak. Di samping itu, siswa pun dapat meningkatkan dan memperluas pengetahuannya melalui tulisan-tulisan.

Berdasarkan observasi yang dilakukan pada senin 12 Januari 2015 di SDN 118 Pinrang pada siswa kelas IV pada pembelajaran bahasa Indonesia masih tergolong rendah. Hal ini dibuktikan berdasarkan nilai ulangan semester lalu yang diperoleh, ada yang masih memperoleh nilai dibawah KKM. Dari 25 siswa hanya 10 orang yang mendapatkan nilai 70 keatas dipresentasekan hanya $40 \%$ siswa yang mencapai ketuntasan dan 15 siswa mendapat nilai dibawah 70 dipersentasekan $60 \%$ siswa yang belum mencapai ketuntasan. Dari data ini dapat dikatakan bahwa nilai bahasa indonesia dikelas IV masih jauh dari taraf keberhasilan yakni berkisar 70\%-100\% dengan kualifikasi baik sehingga dapat dikatakan hasil belajar bahasa indonesia siswa kurang.

Dari permasalahan yang terjadi di kelas IV pada mata pelajaran bahasa indonesia khususnya menulis karangan narasi dipengaruhi oleh 2 faktor yaitu faktor dari guru dan siswa. Dari faktor guru diantaranya: a) Pada proses belajar kurang menghubungkan konsep dan fakta berdasarkan kehidupan nyata siswa. b) karakteristik materi kurang menuntut kemampuan siswa dalam menulis karangan narasi. c) kurangnya pemberian penguatan pada saat proses pembelajaran. Sedangkan Faktor siswa diantaranya: a) rendahnya kepercayaan diri siswa yang ditandai dengan kurang bertanya pada guru dan menjawab pertanyaan pada saat proses pembelajaran. b) Siswa kurang menghubungkan konsep dan fakta pada saat proses pembelajaran. c) rendahnya minat siswa dalam menulis karangan disebabkan kurangnya bimbingan dalam menulis dan penyampaian materi yang kurang bervariasi.
Melihat dari kondisi pada pembelajaran menulis di kelas, perlu adanya perbaikan agar siswa lebih terampil dan kreatif dalam kegiatan menulis karangan. Olehnya itu kita perlu menggunakan model pembelajaran yang tepat untuk masalah tersebut. Jika tidak diatasi dan dibiarkan berlarut-larut, maka akan berdampak negative bagi siswa khususnya pada tingkat pemahaman siswa tentang menulis karangan narasi. Untuk itu peneliti bersama guru secara kolaboratif mencoba memecahkan masalah tersebut dengan menerapkan Model Pembelajaran ARIAS. Peneliti memilih Model Pembelajaran ARIAS karena memiliki manfaat diantaranya a) Siswa sama-sama aktif dalam kegiatan belajar mengajar b) siswa tertantang untuk lebih memperbaiki diri. c) Siswa termotivasi untuk berkompetisi yang sehat antar siswa d) Membantu siswa dalam memahami materi pelajaran e) Membangkitkan rasa percaya diri pada siswa bahwa mereka mampu.

Berdasarkan uraian di atas, maka masalah dalam penelitian ini dirumuskan sebagai berikut: 1) Bagaimanakah Penerapan Model Pembelajaran ARIAS (Assurance, Relevance, Interest, Assessment, Satisfaction) dalam Menulis Karangan Narasi pada Siswa Kelas IV SDN 118 Pinrang dan 2) Apakah Penerapan Model Pembelajaran ARIAS (Assurance, Relevance, Interest, Assessment, Satisfaction) dapat Meningkatkan Hasil Belajar Menulis Karangan Narasi pada Siswa Kelas IV SDN 118 Pinrang?

\section{METODE PENELITIAN}

\section{Pendekatan dan Jenis Penelitian}

Pendekatan yang digunakan adalah pendekatan kualitatif, yaitu pendekatan penelitian untuk mendeskripsikan aktifitas siswa dan guru dalam pelaksanaan tindakan pembelajaran.

Menurut Mc Millan \& Schumacher (Syamsuddin,dkk,2011:73) pendekatan kualitatif adalah "Suatu pendekatan yang juga disebut pendekatan investigasi karena biasanya 
peneliti mengumpulkan data dengan cara bertatap muka langsung dan berinteraksi dengan orang-orang di tempat penelitian". Pendekatan kualitatif ini sangat tepat digunakan dalam pembelajaran Bahasa Indonesia yang mengharuskan peneliti berinteraksi langsung dengan siswa pada saat proses pembelajaran untuk mengetahui perkembangan belajar siswa secara tepat.

Penelitian yang digunakan adalah penelitian tindakan kelas (Classroom action research), dimana Penelitian tidakan kelas sangat sesuai dengan pendekatan kualitatif yang mengharuskan peneliti melakukan observasi langsung untuk melihat keadaan yang terjadi dilapangan. PTK juga merupakan jenis penelitian yang dilakukan secara kolaboratif dan partisipatif.

Menurut Purwadi (Sukidin,dkk,2008) penelitian tindakan kelas (yang selanjutnya disingkat PTK) adalah suatu bentuk penelitian yang dilaksanakan oleh guru untuk memecahkan masalah yang dihadapi dalam melaksanakan tugas pokonya, yaitu mengelola pelaksanaan kegiatan belajar mengajar (KBM) dalam arti luas.

Penelitian Tindakan Kelas (PTK). Menurut Umar dan Kaco (Khalik, 2009: 32) bahwa "PTK bertujuan untuk perbaikan dan peningkatan layanan profesional guru dalam menangani kegiatan belajar mengajar". Pelaksanaan penelitian melalui proses pengkajian berdaur yang terdiri dari empat tahap. Hal ini sejalan dengan pendapat Lewin (Kunandar, 2012: 42) bahwa "penelitian tindakan adalah suatu rangkaian langkah yang terdiri atas empat tahap, yakni perencanaan, tindakan, pengamatan, dan refleksi”.

\section{Fokus Penelitian}

Untuk menjawab permasalahan, ada beberapa fokus penelitian yang diselidiki, yaitu:

a. Proses, yaitu melihat penerapan Model Pembelajaran ARIAS dalam proses belajar mengajar pada mata pelajaran Bahasa
Indonesia khususnya menulis karangan narasi.

b. Hasil, yaitu melihat hasil belajar siswa setelah tes akhir yang diberikan pada setiap siklus dengan menerapkan Model Pembelajaran ARIAS.

\section{Setting dan Subjek Penelitian}

Penelitian Tindakan Kelas ini dilaksanakan di SD Negeri 118 PINRANG selama 1 bulan (Maret sampai dengan April 2015). Adapun mata pelajaran yang diteliti yaitu bahasa Indonesia, Peneliti memilih SD Negeri 118 Pinrang sebagai lokasi penelitian karena ada beberapa faktor diantaranya: 1) karena adanya masalah yang berkaitan dengan hasil belajar disekolah tersebut.2) guru kurang menerapkan model pembelajaran yang bervariasi.3) serta hubungan baik antara calon peneliti dan guru yang dapat memudahkan kerjasama untuk melaksanaan penelitian tindakan kelas yang akan diterapkan.

Subjek dalam penelitian ini adalah guru dan siswa kelas IV SD Negeri 118 Pinrang yang Jumlah siswanya yaitu 25 orang siswa, yang terdiri dari 15 siswa laki-laki dan 10 siswa perempuan.

\section{Rancangan Tindakan ( Perencanaan, Pelaksanaan Tindakan, Observasi, Dan Refleksi )}

Penelitian ini adalah Penelitian Tindakan Kelas yang menerapkan siklus, tiap siklus terdiri atas tahap perencanaan, pelaksanaan tindakan, observasi, dan refleksi. Alasan pelaksanaan penelitian dilakukan karena adanya permasalahan yang terjadi dalam proses pembelajaran.

Sebelum melakukan penelitian, peneliti terlebih dahulu melakukan Pratindakan, yaitu mengidentifikasi masalah sebelum tindakan penelitian dilakukan sehingga menghasilkan gagasan untuk melakukan perbaikan-perbaikan praktek guru dalam mengajar di kelas. Pada tahap ini peneliti terlebih dahulu melaksanakan 
observasi awal untuk melakukan konsultasi dengan kepala sekolah SDN 118 pinrang dan guru kelas tentang kegiatan penelitian yang akan dilaksanakan serta menyesuaikan jadwal penelitian dengan pihak sekolah sehingga tidak mengaganggu aktivitas sekolah. Hasil observasi ini kemudian dikonfirmasikan dengan hasil-hasil kajian teori yang relevan, sehingga menghasilkan suatu program pengembangan tindakan yang dipandang akurat, sesuai situasi lokasi dimana program tindakan dikembangkan.

\section{Teknik dan Prosedur Pengumpulan Data}

Untuk mengumpulkan data penelitian ada cara yang dilakukan, mulai dari observasi (pengamatan), dan tes. Teknik pengumpulan data ini tujuannnya agar memudahkan peneliti dalam kegiatan pembelajaran untuk menunjang keberhasilan pada saat pelaksanaan tindakan dikelas.

Teknik yang digunakan untuk memperoleh data dalam penelitian tindakan kelas ini, adalah :

a. Observasi, teknik yang digunakan untuk mengumpulkan data tentang kegiatan atau partisipasi guru dan siswa dalam proses pembelajaran menulis karangan narasi siswa dengan Peneran Model Pembelajaran ARIAS.

b. Tes, teknik yang digunakan untuk mendapatkan data hasil belajar siswa, yaitu hasil belajar siswa terhadap pembelajaran menulis karangan narasi siswa kelas IV SD Negeri 118 Pinrang.

c. Dokumentasi, teknik yang digunakan untuk mengetahui kondisi awal siswa yang menjadi landasan faktual penelitian, dengan cara pengambilan data awal nilai hasil menulis karangan narasi dan observasi awal untuk mengambil data penyebab dari guru dan dari siswa. Intrumen yang digunakan adalah peneliti sebagai pengumpul data dan pengamat dalam observasi awal.
Adapun alasan peneliti menggunakan 3 Teknik ini untuk memperoleh data dalam penelitian tindakan kelas yaitu untuk memudahkan peneliti untuk mengumpulkan data pada saat pelaksanaan tindakan dikelas.

\section{Teknik Analisis Data Dan Indikator Keberhasilan}

\section{a. Teknik Analisis Data}

Analisis data adalah merangkum secara akurat data dengan benar. Data yang dianalisis adalah aspek siswa yang terdiri atas aktivitas belajar pada saat proses pembelajaran berlangsung dan hasil tugas siswa yang diberikan oleh guru. Teknik analisis data ini memudahkan peneliti dalam menganalisa data-data yang diperoleh pada saat pembelajaran.

Teknik yang digunakan dalam penelitian ini adalah teknik analisis data kualitatif yang terdiri dari tiga tahap kegiatan yaitu :

1) Mereduksi Data adalah proses kegiatan menyeleksi, memfokuskan dan menyederhanakan semua data yang telah diperoleh mulai dari awal pengumpulan data sampai penyusunan laporan penelitian.

2) Menyajikan data adalah kegiatan mengorganisasikan hasil reduksi dengan cara menyusun secara naratif sekumpulan informasi yang telah diperoleh dari hasil reduksi sehingga dapat memberikan penarikan kesimpulan dan pengambilan data.

3) Menarik kesimpulan dan verifikasi data adalah memberikan kesimpulan terhadap hasil penafsiran dan evaluasi yang mencakup pencarian makna data serta memberikan penjelasan selanjutnya.

Adapun alasan menggunakan teknik analisis data kualitatif yaitu memudahkan peneliti dalam mengumpulkan dan menyajikan data secara naratif.

\section{b. Indikator keberhasilan}

Indikator keberhasilan dalam penelitian ini adalah: 


\section{a. Indikator Proses}

Kriteria yang digunakan untuk mengukur indikator proses, yaitu aktivitas guru dan aktivitas siswa dalam proses pembelajaran, minimal 70\% keterlaksanaan langkah-langkah yang sesuai dengan Model Pembelajaran ARIAS dalam pembelajaran menulis karangan narasi dengan kualifikasi baik (B) berada pada rentang 70\%-100\% tingkat keberhasilan.

\section{b. Indikator Hasil}

Penelitian dianggap berhasil apabila minimal 70\% siswa dikelas telah memperoleh nilai 70 sesuai dengan KKM sekolah dengan kualifikasi baik (B) berada pada rentang 70\%-100\%.

Berdasarkan kriteria tersebut, maka Peneliti dengan guru menentukan tingkat keberhasilan tindakan pada penelitian ini dilihat dari hasil belajar secara individu pada setiap siklus yaitu apabila $70 \%$ dari jumlah siswa yang mengikuti proses belajar mengajar mencapai taraf keberhasilan minimal, optimal, atau bahkan maksimal, maka proses belajar mengajar dikatakan berhasil. Sebaliknya jika $70 \%$ atau lebih dari jumlah siswa yang mengikuti proses belajar mengajar mencapai taraf keberhasilan kurang (di bawah taraf minimal), maka proses belajar mengajar berikutnya hendaknya bersifat perbaikan (remedial).

Merujuk dari pendapat tersebut, maka indikator hasil belajar siswa dalam penelitian tindakan kelas ini adalah "jika 70\%" atau lebih dari jumlah siswa yang mengikuti proses pembelajaran berhasil menguasai $\geq 70 \%$ materi pelajaran yang diajarkan, maka penelitian sudah berhasil sehingga tidak perlu dilanjutkan ke siklus berikutnya. Akan tetapi, jika kurang dari $70 \%$ dari jumlah siswa yang mengikuti proses pembelajaran berhasil menguasai $<70 \%$ materi pelajaran yang diajarkan, maka penelitian perlu dilanjutkan ke siklus berikutnya."

\section{HASIL PENELITIAN}

Kegiatan menulis karangan merupakan kegiatan yang melatih kemampuan siswa dalam hal menulis. Selain memperindah tulisan, mengarang juga membantu siswa untuk mampu menyusun sebuah karya tulis yang baik. Dimana menyusun sebuah kalimat menjadi bacaan yang sempurna perlu latihan yang sering karena keterampilan menulis merupakan keterampilan tersulit diantara ke 4 keterampilan berbahasa yaitu keterampilan menyimak, keterampilan berbicara, dan keterampilan membaca karena memiliki bobot penilaian tersendiri dalam menulis karangan. Untuk menunjang kemampuan menulis siswa menjadi lebih baik yaitu dengan berlatih menulis karangan dan memperbanyak membaca buku untuk menambah wawasan kosa kata dan pengetahuan.

Penerapan Model Pembelajaran ARIAS juga baik sebagai alternatif guru untuk membantu siswa belajar menulis karangan narasi. Menurut Ahmadi, dkk (2011) Model Pembelajaran (ARIAS) Assurance, Relevance, Interest, Assessment, Satisfaction merupakan cara belajar yang efektif dan efesien, karena pada pembelajaran ARIAS melibatkan lima komponen dalam proses pembelajaran yaitu, fase assurance (A), fase relevance (R), fase interest (I), fase assessment, dan fase satisfaction (S). Kelima komponen tersebut merupakan satu kesatuan yang diperlukan dalam kegiatan pembelajaran. Adapun kelebihan model pembelajaran ARIAS yaitu menurut Umroh (2013) menyatakan kelebihan model pembelajaran ARIAS (1) Siswa sama-sama aktif dalam kegiatan belajar mengajar.(2) Siswa tertantang untuk lebih memperbaiki diri. (3) Siswa termotivasi untuk berkompetisi yang sehat antar siswa. (4) Membantu siswa dalam memahami materi pelajaran. (5) Membangkitkan rasa percaya diri pada siswa bahwa mereka mampu.

Berdasarkan penelitian pada siklus I dan Siklus II ditemukan adanya peningkatan hasil belajar siswa dalam menulis karangan narasi. 
Siklus I merupakan langkah awal perbaikan pembelajaran setelah dirumuskan hasil pratindakan. Pada siklus ini Model Pembelajaran ARIAS ( Assurance, Relevance, Interest, Assessment Satisfaction) diuji keefektifannya. Fokus yang dinilai pada pembelajaran ini berdasarkan fokus proses yaitu pada aktivitas guru dan siswa didapatkan kelebihan dan kekurangan yaitu pada awal pertemuan siswa kurang percaya diri untuk menjawab ataupun bertanya berdasarkan materi yang disampaikan, pada pembelajaran dengan menghubungkan konsep dan fakta sesuai kehidupan nyata siswa kurang di mengerti oleh siswa, kemudian dalam proses kegiatan menulis karangan pada siklus I belum mampu membuat karangan narasi dengan baik. Hal tersebut ditandai dengan kurangnya pengetahuan siswa tentang menulis karangan mulai dari penggunaan huruf kapital, tanda baca dan ejaan, tidak mengerti penyusunan paragraf dan cara membuat kerangka karangan serta cara menentukan tema karangan, untuk mengetahuai aktivitas guru dan siswa, peneliti menggunakan lembar observasi guru dan siswa yang terdiri dari 5 tahap model pembelajaran ARIAS dan setiap tahap terdiri dari 3 indikator umum kemudian setiap indikator terdiri dari 3 deskriptor yang digunakan untuk melihat perkembangan proses pembelajaran menulis karangan. Kemudian hasil belajar siswa masih dalam kategori rendah atau kurang yaitu dilihat dari tes evaluasi akhir yang dikerjakan siswa setiap pertemuan akhir siklus.

Tindakan pada siklus I menunjukkan kemampuan yang belum maksimal. Kekurangan yang terdapat pada siklus ini bersumber dari aspek guru dan juga aspek siswa. Diantaranya guru kurang dalam pemberian motivasi dan memberikan pertanyaan yang dapat meningkatkan kepercayaan diri siswa, guru kurang dalam penyampaian materi, guru kurang membimbing siswa yang kesulitan sedangkan siswa kurang percaya diri dalam menjawab ataupun bertanya, siswa tidak fokus pada pembelajaran. Kekurangan yang ditemukan pada saat proses pembelajaran tersebut perlu adanya perbaikan, dengan meningkatkan kemampuan guru dalam pemberian motivasi dan pengembangan materi yang lebih luas sehingga mampu menarik minat siswa dengan melihat situasi belajar siswa.

Berdasarkan pertemuan yang terjadi pada siklus I diketahui bahwa dari 25 orang siswa hanya 13 siswa yang memperoleh nilai $\geq 70$ atau sekitar $52 \%$ sementara 12 siswa yang memperoleh nilai $\leq 70$ atau sekitar $48 \%$. Dengan demikian masih terdapat 12 siswa yang memperoleh nilai dibawah KKM sekolah atau dibawah nilai 70. Kekurangan yang terjadi pada siklus ini disebabkan oleh : 1). Pemberian motivasi masih kurang, 2). Kurangnya bimbingan yang di beri siswa pada proses pembelajaran , 3) siswa kurang memperhatikan penjelasan dari guru. Sehingga proses pembelajaran tidak sesuai dengan yang diharapkan.

Pada tindakan siklus II, Model Pembelajaran ARIAS masih diterapkan dengan melaksanakan 5 tahap yang tiap tahapnya terdiri dari 3 indikator umum dan tiap indikator terdiri dari 3 deskriptor. Pada siklus II, semua kekurangan yang ada pada siklus I baik pada guru maupun siswa sudah dapat diperbaiki. Seperti pada kegiatan belajar siswa mengalami peningkatan dalam penguasaan materi menulis karangan, dimana karangan yang dibuat siswa mengalami peningkatan yang terlihat dari siswa mengerjakan soal LKS yaitu menulis karangan yang dilaksanakan setiap pertemuan kemudian dari hasil belajar siswa juga mengalami peningkatan yang ditandai dengan hasil tes evaluasi belajar siswa yang mengalami peningkatan .

Dari hasil perbaikan Model Pembelajaran ARIAS sudah terjadi peningkatan dan perubahan terhadap guru dan siswa dari hasil belajar maupun pada saat proses pembelajaran berlangsung sudah cukup baik. Sejalan dengan pendapat Nawawi ( Susanto, 2013) 
Menyatakan bahwa hasil belajar diartikan sebagai tingkat keberhasilan siswa dalam mempelajari materi pelajaran di sekolah yang dinyatakan dalam skor perolehan dari hasil tes pembelajaran tertentu.

Dilihat dari aktivitas belajar, siswa terlihat nyaman menerima pelajaran dan termotivasi dalam kegiatan pembelajaran, sehingga nilai yang diperoleh jauh lebih baik. Hal ini terlihat dari pencapain hasil belajar siswa yaitu sekitar $80 \%$ siswa yang memperoleh nilai $\geq 70$ dan $20 \%$ siswa yang memperoleh nilai $\leq 70$.

Berdasarkan gambaran data pada pembahasan yang diuraikan di atas, sangat jelas bahwa hasil belajar siswa dari siklus I sampai dengan siklus II mengalami peningkatan yang drastis. Dengan penerapan model ARIAS pembelajaran menulis karangan narasi dapat meningkat dan mampu meningkatkan hasil belajar siswa kelas IV SDN 118 pinrang.

\section{KESIMPULAN}

Berdasarkan rumusan

masalah, pelaksanaan (tindakan), hasil dan pembahasan penelitian dapat disimpulkan bahwa; (1) Penerapan Model Pembelajaran ARIAS dapat meningkatkan kemampuan menulis karangan narasi siswa kelas IV SDN 118 Pinrang. (2) Penerapan Model Pembelajaran ARIAS dapat meningkatkan hasil belajar menulis karangan narasi pada siswa Kelas IV SDN 118 Pinrang. Adapun hasil belajar siswa pada penelitian ini, dengan menerapkan model pembelajaran ARIAS yang dibuktikan berdasarkan siklus I hasil belajar siswa masih tergolong kategori Kurang (K) yaitu belum mencapai kriteria ketuntasan minimal sehingga dilanjutkan ke siklus II dan didapatkanlah hasil belajar siswa dengan kategori Baik (B).

\section{DAFTAR PUSTAKA}

Abidin, Yusran.2012. Pembelajaran Bahasa Berbasis Pendidikan Karakter. Jakarta:

Refika Aditama.

Ahmadi, dkk. 2011. Strategi Pembelajaran
Sekolah Terpadu. Jakarta: PT. Prestasi Pustakaraya.

Depdiknas. 2006. Kurikulum Satuan Pendidikan Mata Pelajaran Bahasa Indonesia. Jakarta: Depdiknas.

Khalik, Abdul. 2007. Pembelajaran Bahasa Indonesia Kelas Tinggi. Parepare: Universitas Negeri Makassar. - 2008. Pengembangan Pembelajaran Bahasa Indonesia. Parepare: Universitas Negeri Makassar.

.2009. Penelitian Tindakan Kelas. Parepare: Universitas Negeri Makassar.

Kunandar. 2012. Langkah Mudah Penelitian Tindakan Kelas Sebagai Pengembangan Profesi Guru.Jakarta: RajaGrafindo Persada.

Nurudin. 2010. Dasar-dasar Penulisan. Malang: UMM Press.

Rahman, Muhammat dan Amri, Sofan.2014. model pembelajaran ARIAS. Jakarta : PT. Prestasi pustaka raya.

Sinring, Abdullah, dkk.2012. Pedoman Penulisan Skripsi Program S-1 Fakultas Ilmu Pendidikan UNM. Makassar: Fakultas Ilmu Pendidikan UNM.

Slamet, St.Y.2007. Dasar-Dasar Keterampilan Berbahasa Indonesia.Surakarta:

Universitas sebelas Maret Press.

Sukidin, dkk.2008. Manajemen Penelitian Tindakan Kelas. Jakarta : PT. Insan Cendekia.

Sujana, Nana. 2006. Penelitian Hasil Belajar Mengajar. Bandung: Sinar Baru Algensindo.

Susanto, Ahmad.2013.Teori Belajar \& Pembelajaran di Sekolah Dasar. Jakarta: Kencana Prenada Media Group.

Syamsuddin. dan S. Vismamai. (Eds). 2011. Metode Penelitian Pendidikan Bahasa.Bandung:Remaja Rosdakarya offset.

Tampubolon, Saur. 2014. Penelitian Tindakan Kelas Sebagai Pengembangan Profesi Pendidik dan Keilmuan. Jakarta: Erlangga. 